\title{
EFEKTIVITAS MODEL EXPLICIT INSTRUCTION MENGGUNAKAN MEDIA VIDEO UNTUK MENINGKATKAN HASIL BELAJAR PEMBUATAN POLA BUSANA WANITA
}

\author{
Ni Nyoman Ratih Diana Utari ${ }^{1}$, I Dewa Ayu Made Budhyani ${ }^{2}$, Made Diah Angendari ${ }^{3}$ \\ Program Studi Pendidikan Kesejahteraan Keluarga, Fakultas Teknik dan Kejuruan \\ Universitas Pendidikan Ganesha \\ Singaraja, Indonesia
}

e-mail: ratihdianau1309@gmail.com, ayu.budhyani@gmail.com, diah.angendari@undiksha.ac.id

\begin{abstract}
Abstrak
Penelitian ini bertujuan untuk mengetahui efektivitas penerapan model explicit instruction menggunakan media video untuk meningkatkan hasil belajar pembuatan pola busana wanita kelas X Tata Busana SMK Negeri 1 Seririt. Adanya situasi pandemic Covid-19, proses pembelajaran dengan pengimplementasi model explicit instruction menggunakan media video dilaksanakan dengan menggunakan aplikasi google meet. Jenis penelitian ini adalah preexperimental dengan desain one shot case study. Penelitian ini hanya menggunakan satu kelompok sampel yang diberikan model explicit instruction menggunakan media video. Populasi dalam penelitian adalah seluruh siswa kelas X Tata Busana di SMK Negeri 1 Seririt tahun ajaran 2020/2021 yang berjumlah 22 siswa. Penentuan sampel pada penelitian ini menggunakan teknik sampel jenuh. Pengumpulan data dalam penelitian ini dengan metode tes untuk mengetahui hasil belajar kognitif dan psikomotor siswa dan metode observsi untuk mengetahui hasil belajar afektif siswa dan kuesioner/angket digunakan untuk mengetahui kelayakan media video dengan menggunakan model angket tertutup. Berdasarkan analisis dengan statistik deskriptif diperoleh hasil perhitungan dengan uji-t diperoleh bahwa thitung $=19,86$ sedangkan tabel dapat dilihat pada tabel statistik pada taraf signifikansi $5 \%$ dengan derajat kebebasan $(\mathrm{dk})=\mathrm{n}-1=22-1=21$, hasil dieroleh untuk tabel sebesar 2,080. Ini berarti thitung $>$ tabel. dan hasil dalam menentukan efektivitas dari perlakuan (treatment) yaitu sebesar 4,17 , termasuk kriteria efektivitas tinggi karena berada pada rentangan 0,8<ES. Berarti $\mathrm{H} 0$ ditolak dan $\mathrm{H} 1$ diterima sehingga dapat disimpulkan bahwa model explicit instruction menggunakan media video efektif digunakan untuk meningkatkan hasil belajar siswa dalam pembuatan pola busana wanita di SMK Negeri 1 Seririt.
\end{abstract}

Kata kunci : Hasil Belajar, Model explicit instruction, Media video, Pola Busana.

\begin{abstract}
This study aims to determine the effectiveness of applying the explicit instruction model using video media to improve the learning outcomes of making women's clothing patterns for class X SMK Negeri 1 Seririt, with a pandemic situation like this, in applying the explicit instruction model using video media the researcher uses the google application meet. This type of research is pre-experimental with a one shot case study design. This study only uses one sample group that is given an explicit instruction model using video media. The population in the study were all students of class X Fashion Design at SMK Negeri 1 Seririt in the academic year 2020/2021, totaling 22 students. Determination of the sample in this study using a saturated sample technique. The data collection in this study was the test method to determine the student's cognitive and psychomotor learning outcomes and the observation method to determine the student's affective learning outcomes and the questionnaire / questionnaire was used to determine the feasibility of video media using a questionnaire model. closed questionnaire. Based on the analysis with descriptive statistics, the results of the calculation with the t-test show that $t=19.86$
\end{abstract}


while the $t$ table can be seen in the statistical table at the $5 \%$ significance level with degrees of freedom $(\mathrm{dk})=\mathrm{n}-1=22-1=21$, the results are obtained. for $\mathrm{t}$ table of 2.080 . This means tcount $>$ ttable. and the results in determining the effectiveness of the treatment (treatment) is 4.17 , including the criteria for high effectiveness because it is in the range $0.8<\mathrm{ES}$. It means that $\mathrm{H} 0$ is rejected and $\mathrm{H} 1$ is accepted, so it can be concluded that the explicit instruction model using video media is effectively used to improve student learning outcomes in making women's clothing patterns at SMK Negeri 1 Seririt.

Keywords: Learning Outcomes, Explicit Instruction Model, Video Media, Clothing Patterns.

\section{PENDAHULUAN}

Pada zaman ini, perkembangan ilmu pengetahuan dan teknologi telah membawa perubahan yang cukup signifikan dihampir semua aspek kehidupan manusia, Indonesia kini memasuki era revolusi industry 4.0 dimana era ini menghubungkan antara manusia dengan penggunaan teknologi dihampir semua kegiatannya, salah satunya dalam proses pembelajaran. Revolusi pembelajaran berbasis teknologi sudah menjadi keharusan karena bila tidak maka pembelajaran yang dilaksanakan tidak akan efektif dan berdampak besar dalam konteks peningkatan kualitas pendidikan.

Pendidikan merupakan hal yang penting dan wajib didapatkan oleh setiap individu, terutama anak-anak sebagai generasi penerus bangsa. Hal ini tertuang dalam Undang-undang Nomor 20 tahun 2003 Bab I Pasal (1) tentang sistem pendidikan nasional. Pendidikan adalah usaha sadar dan terencana untuk mewujudkan suasana belajar dan proses pembelajaran agar peserta didik secara aktif mengembangkan potensi dirinya, kepribadian, kecerdasan akhlak mulia, serta keterampilan yang diperlukan dirinya, masyarakat, bangsa dan Negara. Dari dasar inilah dapat diketahui bahwa pendidikan di Indonesia bertujuan untuk menjadikan setiap individu pribadi yang berkualitas. Pendidikan yang bertujuan untuk menjadikan individu berkualitas ini membutuhkan tempat untuk mengimplementasikannya dan sekolah merupakan salah satu wadah yang tepat untuk melaksanakan pendidikan.

Undang-undang Nomor 2 Tahun 1989 Pasal 9 menyatakan bahwa sekolah adalah satuan pendidikan yang berjenjang dan berkesinambungan untuk menyelenggarakan kegiatan belajar mengajar. Pembelajaran adalah situasi formal yang diprogramkan oleh guru dalam usahanya membagikan ilmu kepada peserta didik berdasarkan kurikulum dan tujuan yang hendak dicapai. Dalam proses belajar mengajar terdiri dari pendidik (guru) dan peserta didik (siswa). Untuk mencapai tujuan dalam kegiatan belajar mengajar diharapkan antara pendidik dan peserta didik terdapat interaksi yang baik. Peran dan cara guru pada saat mengajar sangatlah berpengaruh terhadap proses belajar mengajar serta hasil belajar siswa. Dalam hal ini, pendidik dituntut untuk beperan aktif untuk mengantarkan peserta didik menuju tujuan pendidikan sehingga hasil belajar sesuai dengan yang diinginkan. Berdasarkan Peraturan Pemerintah Republik Indonesia Nomor 17 Tahun 2010 tentang Pengelolaan dan Penyelenggaraan Pendidikan menyatakan jenjang pendidikan formal (sekolah) dibedakan atas, Taman Kanak (TK), Sekolah Dasar (SD), Sekolah Menengah Pertama (SMP), Sekolah Menengah Atas (SMA) atau Sekolah Menengah Kejuruan (SMK), dan Universitas/Sekolah Tinggi.

$$
\text { Sekolah Menengah Kejuruan }
$$

(SMK) merupakan jenjang pendidikan menengah vokasional pada pendidikan formal di Indonesia yang ditempuh setelah lulus dari Sekolah Menengah Pertama. SMK memiliki beberapa kelompok bidang studi keahlian salah satunya adalah kelompok pariwisata yang memiliki beberapa program keahlian salah satunya yaitu Kompetensi Keahlian Tata Busana. Menurut Oktapiani (2014: 181) Keahlian Tata Busana adalah kompetensi keahlian yang mempersiapkan peserta didik dan 
membekali peserta didik dengan keterampilan, pengetahuan agar menjadi manusia produktif, mampu bekerja mandiri, dan menciptakan lapangan pekerjaan di dunia kerja. Selain itu keahlian tata busana juga mempersiapkan lulusannya agar memiliki karir, ulet dan gigih dalam berkompetensi dengan ilmu pengetahuan dan teknologi (Oktapiani, 2014: 181). SMK merupakan sekolah yang menyiapkan peserta didiknya untuk dapat bekerja dalam bidangnya masing-masing ini, kini telah tersebar di banyak wilayah di Indonesia salah satunya yaitu di daerah Buleleng, Bali. Salah satu Smk yang ada di buleleng yaitu SMK Negeri 1 Seririt.

SMK Negeri 1 Seririt terletak di jalan kembang tebel, Lokapaksa, Kec. Seririt, Kab. Buleleng, Prov.Bali. SMK Negeri 1 Seririt memiliki program keahlian yang meliputi Akomodasi Perhotelan, Tata Boga, Tata Busana, Akutansi. Tata busana yang merupakan salah satu program keahlian di
SMK Negeri 1 Seririt memiliki Mata Pelajaran Pembuatan Pola Busana Wanita. Dari hasil pengamatan (observasi) di SMK Negeri 1 Seririt kelas X Tata Busana pada mata belajaran Pembuatan Pola Busana Wanita permasalahan yang ditemukan yakni rendahnya hasil belajar siswa pada mata pelajaran pembuatan pola busana wanita adapun Kriteria Ketuntasan Minimum (KKM) tahun 2019/2020 pada mata pelajaran pembuatan pola busana wanita yakni untuk KKM pengetahuan yaitu 74 dan KKM keterampilan yaitu 75. Jumlah siswa kelas X Tata Busana di SMK Negeri 1 Seririt yaitu 33 orang. Dari ranah pengetahuan (kognitif) terdapat 54,5\% yang tidak tuntas dan $45,4 \%$ yang dinyatakan tuntas sedangkan pada ranah keterampilan psikomotor terdapat 60,6\% yang tidak tuntas dan $39,3 \%$ yang dinyatakan tuntas. Untuk lebih jelasnya dapat dilihat pada Tabel 1.1.

Tabel 1. Kriteria Ketuntasan Minimum Tahun 2019/2020

\begin{tabular}{cccccc}
\hline \multicolumn{5}{c}{ Kriteria Ketuntasan minimum } \\
$(\mathrm{KKM})$
\end{tabular}

(sumber: data SMK Negeri 1 Seririt)

Berdasarkan hasil pengamatan (observasi) dengan guru mata pelajaran pembuatan pola busana wanita, rendahnya hasil belajar siswa pada mata pelajaran pembuatan pola busana wanita disebabkan oleh beberapa permasalahan diantaranya 1) saat ini proses pembelajarannya masih menggunakan model konvensional yakni lebih dominan menggunakan metode ceramah dan menggunakan media pembelajaran berupa job sheet, 2) minimnya penggunaan media pembelajaran berbasis teknologi yang menyebabkan proses pembelajaran menjadi kurang bervariatif, 3) mata pelajaran pembuatan pola merupakan mata pelajaran yang menuntut siswa untuk memiliki pengetahuan prosedural yang terstruktur, 4) rendahnya minat siswa dalam mengikuti proses belajar mengajar yang dapat dilihat dari keaktifan siswa di kelas, 5) kemampuan siswa menerima informasi dalam proses belajar mengajar berbeda-beda. 


\begin{abstract}
Kemampuan guru dalam menyediakan bahan ajar dan model pembelajaran yang sesuai dalam setiap proses belajar mengajar sangatlah diperlukan untuk mencapai tujuan pembelajaran. Macam-macam model pembelajaran yang sesuai dalam setiap proses pembelajaran terbagi atas 1) model pembelajaran langsung, 2) model pembelajaran berbasis masalah, 3) model pembelajaran pendidikan matematika, 4) model pembelajaran kontekstual, 5) model pembelajaran kooperatif (Afandi, 2013:16). Selanjutnya, dari macam-macam model pembelajaran yang telah disebutkan seorang guru harus mampu memilih dan menentukan jenis model pembelajaran yang sesuai dengan mata pelajaran yang diajarakan sehingga tercapainya tujuan pembelajaran yang telah direncanakan. Penggunaan model pembelajaran dan media pembelajaran yang sesuai dapat menjadikan pelajar lebih menarik minat siswa untuk belajar dan mempengaruhi hasil belajar siswa. Salah satu model pembelajaran yang dapat menjadikan pembelajaran lebih menarik minat belajar serta meningkatkan hasil belajar yaitu model pembelajaran explicit instruction (pembelajaran langsung) (Afandi, 2013:23).
\end{abstract}

Model pembelajaran explicit instruction adalah suatu pendekatan pembelajaran yang dirancang untuk mengembangkan kegiatan belajar siswa tentang pengetahuan deklaratif dan pegetahuan prosedural yang diajarkan dengan pola selangkah demi selangkah (Suyatno, 2009:127). Selaras dengan karakteristik model pembelajaran explicit instruction, di SMK Negeri 1 Seririt terdapat mata pelajaran pembuatan pola busana wanita yang prosedur pembelajarannya seharusnya diajarkan selangkah demi selangkah sehingga kompetensi peserta didik dapat tercapai dengan maksimal. Kesuksesan dalam proses belajar mengajar tidak hanya didukung oleh model pembelajaran namun juga didukung oleh media pembelajaran.

Media pembelajaran merupakan segala sesuatu yang dapat digunakan untuk menyalurkan pesan atau isi pelajaran. Media pembelajaran yang baik harus mampu merangsang pikiran,perasaan, kemampuan siswa, dan perhatian siswa (Sudjana, 2004:41). Menurut Sanjaya (2011:211) Media pembelajaran yang mampu merangsang dan menarik perhatian siswa dalam belajar yakni media audio visual karena audio visual merupakan media pengajaran yang mengaktifkan mata dan telinga peserta didik pada saat proses belajar mengajar berlangsung. Media audio visual yaitu jenis media yang selain mengandung unsur suara juga mengandung unsur gambar yang lihat dan mata pelajaran pembuatan pola busana wanita merupakan salah satu mata pelajaran yang proses pembuatannya secara terstruktur dan memerlukan adanya unsur gambar serta suara untuk memperjelas proses pembuatannya (Sanjaya, 2011:211).

Berdasarkan permasalahan yang terjadi di SMK Negeri 1 Seririt penulis bermaksud untuk melakukan penelitian dengan judul Efektivitas Model Explicit Instruction Menggunakan Media Video Untuk Meningkatkan Hasil Belajar Pembuatan Pola Busana Wanita di SMK Negeri 1 Seririt. Penelitian ini bertujuan untuk mengetahui efektivitas penerapan model explicit instruction menggunakan media video untuk meningkatkan hasil belajar pembuatan pola busana wanita di kelas X Tata Busana SMK Negeri 1 Seririt. Aplikasi yang digunakan dalam proses pembelajaran daring saat ini yaitu aplikasi google meet. Aplikasi ini dapat membantu dan memudahkan para guru dan siswa saat melakukan proses pembelajaran jarak jauh secara online seperti, aplikasi panggilan video yang berkualitas tinggi dapat digunakan secara gratis dengan jumlah peserta \pm 100 orang, keamanan yang tinggi, dapat digunakan disegala perangkat.

\section{METODE PENELITIAN}

Penelitian yang akan digunakan dalam penelitian ini adalah dengan menggunakan metode pre experimental design dengan jenis one shot case study. Metode ini satu kelompok eksperimen diberikan perlakuan (treatment) setelah dilakukan perlakuan kepada siswa, maka berikan test untuk mengukur tingkat hasil 
belajar siswa sesudah diberikan perlakuan berupa post test, setelah memberikan post test akan didapatkan data hasil dari eksperimen dimana hasil belajar siswa pada mata pelajaran pembuatan pola busana wanita meningkat atau tidak. Pada penelitian ini membandingkan antara nilai KKM yaitu pengetahuan 74 dan keterampilan 75 dengan nilai post test untuk menentukan seberapa besar meningkatnya hasil belajar yang diakibatkan dari treatment yang telah diberikan. Kegiatan penelitian ini bertujuan untuk menilai suatu perlakuan pendidikan terhadap tingkah laku siswa atau menguji hipotesis tentang ada-tidaknya pengaruh perlakuan yang diberikan. Melalui penelitian eksperimen ini, peneliti ingin mengetahui bahwa penerapan model explicit instruction meggunakan video dapat meningkatkan hasil belajar siswa pada mata pelajaran pembuatan pola busana wanita.

Penelitian ini dilakukan di SMK Negeri 1 Seririt. Sampel penelitian ini adalah kelas $X$ Tata Busana yang berjumlah 22 siswa, pengambilan sampel dilakukan dengan teknik sampling jenuh. variabel yang digunakan adalah variabel bebas: model pembelajaran explicit instruction menggunakan media video dan variabel terikat: hasil belajar siswa. Teknik pengumpulan data menggunakan metode tes, lembar observasi dan kuesioner/angket. metode tes untuk mengetahui hasil belajar kognitif dan psikomotor siswa dan metode observsi untuk mengetahui hasil belajar afektif siswa dan kuesioner/angket digunakan untuk mengetahui kelayakan media video dengan menggunakan model kuesioner/angket tertutup. Metode dan teknik analisis data Untuk desain penelitian one shot case study maka menggunakan uji T (t-test) dengan rumus berikut (Dantes, 2017:63).

$$
\mathrm{t}=\frac{\bar{x}-\mu}{\sqrt{\frac{\sum D^{2}}{N\left(N^{2}-1\right)}}}
$$

(Sumber: Dantes, 2017:63)

Rumus ini digunakan untuk menghitung keberhasilan perlakuan yang telah diberikan kepada subyek peneliti dan digunakan untuk one grup atau yang observasinya hanya menggunakan satu kelas. Hasil data inilah yang dianalisis dengan rumus $t_{\text {hitung }}>t_{\text {tabel }}$ berdasarkan $\mathrm{dk}=\mathrm{n}-1$ pada taraf signifikan $5 \%$, sehingga hasil tersebutlah yang dapat menunjukkan apakah perlakuan yang diberikan efektif atau tidak. Bila ingin diketahui efektivitas dari perlakuan (treatment) dapat menggunakan rumus efektivitas size (ES) sebagai berikut:

$$
\mathrm{ES}=\mathrm{t}_{\text {hitung }} \sqrt{ } 1 \mathrm{n}
$$

(Sumber: Dantes, 2017:65)

Tabel 2 Kriteria Efektivitas

\begin{tabular}{cc}
\hline Interval & Kriteria \\
\hline $\mathrm{ES} \leq 0,20$ & efektivitas rendah \\
$0,2<\mathrm{ES} \leq 0,8$ & efektifitas sedang \\
$0,8<\mathrm{ES}$ & efektifitas tinggi \\
\hline
\end{tabular}

(Sumber: Dantes, 2017:65)

\section{HASIL DAN PEMBAHASAN}

Penelitian ini dilaksanakan dengan cara mengikuti alur penelitian experiment. Langkah kerja dalam penelitian ini terdiri atas tahap perencanaan, tahap pelaksanaan dan tahap akhir. Tahapan pelaksanaan penelitian merupakan penerapan rancangan penelitian yang telah disusun berupa model pembelajaran explicit instruction menggunakan media video untuk meningkatkan hasil belajar pembuatan pola busana wanita. Data yang disajikan berupa tes objektif, lembar observasi dan tes kinerja. Sebelum memberikan posttest, terlebih dahulu peneliti memberikan treatment 
pembelajaran dengan model explicit instruction menggunakan media video untuk meningkatkan hasil belajar siswa. Selanjutnya, dilakukan posttest pada kelas one shot case study. Tes ini dilakukan untuk mengetahui kemampuan yang dicapai siswa setelah berakhirnya proses belajar mengajar. Tes yang digunakan dalam penelitian ini berbentuk tes objektif berjumlah 20 soal dan tes kinerja berjumlah 6 soal, dan lembar observasi afektif berjumlah 15 aspek penilaian. Untuk mengetahui tingkat efektivitas model explicit instruction menggunakan media video untuk meningkatkan hasil belajar maka data hasil tes siswa dianalisis dengan menggunakan uji-t (t-test) terhadap skor post-test. Berdasarkan Kriteria Ketuntasan Minimum (KKM) yang ditetapkan sekolah, data tersebut menunjukan dari 22 siswa yang mengikuti pembelajaran dengan menerapkan model pembelajaran explicit instruction menggunakan media video, siswa dapat meningkatkan kompetensi sesuai yang diharapkan dimana seluruh siswa sebanyak 22 orang mencapai Kriteria Ketuntasan Minimum (KKM) yang ditentukan sekolah yaitu 74 untuk aspek kognitif dan 75 untuk aspek psikomotor. Hasil analisis uji-t ( $t$-test) pada efektivitas model pembelajaran explicit instruction menggunakan video untuk meningkatkan hasil belajar siswa kelas X Tata Busana pada mata pelajaran pembuata pola busana wanita di SMK Negeri 1 Seririt. Berdasarkan hasil perhitungan uji-t adalah 19,86 dengan efektivitas sebesar 4,17 yang temasuk kriteria efektivitas tinggi, sehingga $\mathrm{H} 0$ ditolak dan $\mathrm{H} 1$ diterima.

Contoh perhitungan Uji-t dan efektivitas Size hasil belajar kognitif siswa dicontohkan sebagai berikut:

Aplikasi Rumus Uji t (t-test)

$$
\begin{array}{ll}
\mathrm{t}=\frac{\bar{x}-\mu}{\sqrt{\frac{\sum D^{2}}{N\left(N^{2}-1\right)}}} & \mathrm{t}=\frac{11,6}{\sqrt{\frac{4817}{10.626}}} \\
\mathrm{t}=\frac{85,6-74}{\sqrt{\frac{4317}{22\left(22^{2}-1\right)}}} & \mathrm{t}=\frac{11,6}{\sqrt{0,45}} \\
\mathrm{t}=\frac{11,6}{0,67} & \mathrm{t}=17,3
\end{array}
$$

Contoh perhitungan Uji-t dan efektivitas Size hasil belajar afektif siswa dicontohkan sebagai berikut: Aplikasi Rumus Uji t (t-test)

$$
\begin{array}{ll}
\mathrm{t}=\frac{\bar{x}-\mu}{\sqrt{\frac{\Sigma D^{2}}{N\left(N^{2}-1\right)}}} & \mathrm{t}=\frac{15,13}{\sqrt{\frac{5299,5}{10626}}} \\
\mathrm{t}=\frac{52,63-37,5}{\sqrt{\frac{5299,5}{22\left(22^{2}-1\right)}}} & \mathrm{t}=\frac{15,13}{\sqrt{0,49}} \\
\mathrm{t}=\frac{15,13}{0,70} & \mathrm{t}=21,6
\end{array}
$$

Contoh perhitungan Uji-t dan efektivitas Size hasil belajar psikomotor siswa dicontohkan sebagai berikut: Aplikasi Rumus Uji t ( $t$-test)

$$
\begin{array}{ll}
\mathrm{t}=\frac{\bar{x}-\mu}{\sqrt{\frac{\Sigma D^{2}}{N\left(N^{2}-1\right)}}} & \mathrm{t}=\frac{16,63}{\sqrt{\frac{6882}{10626}}} \\
\mathrm{t}=\frac{91,63-75}{\sqrt{\frac{6882}{22\left(22^{2}-1\right)}}} & \mathrm{t}=\frac{16,63}{\sqrt{0,64}} \\
\mathrm{t}=\frac{16,63}{0,80} & \mathrm{t}=20,7
\end{array}
$$

Berdasarkan hasil analisis uji-t dari masing-masing ranah (kognitif,afektif dan psikomotor) tersebut kemudian dicari ratarata dari ketiga ranah tersebut digunakan untuk menghitung keberhasilan perlakuan yang telah diberikan kepada siswa untuk meningkatkan hasil belajar secara keseluruhan dengan perhitungan sebagai berikut :

Rata-rata uji-t $=\frac{\sum u j i-t}{n}=\frac{59,6}{3}=19,86$

Bila ingin diketahui efektivitas dari perlakuan (treatment) dapat menggunakan rumus efektivitas size (ES) sebagai berikut:

$$
\begin{aligned}
\text { ES } & =t_{\text {hitung }} \sqrt{1 / \mathrm{n}} \\
& =19,86 \sqrt{1 / 22} \\
& =19,86 \times 0,21 \\
& =4,17 \text { ( Efektivitas Tinggi) }
\end{aligned}
$$

Berdasarkan hasil perhitungan ratarata uji-t di atas dapat diketahui bahwa $t_{\text {hitung }}$ 
$=19,86$ sedangkan $t_{\text {tabel }}$ dapat dilihat pada tabel statistik pada taraf signifikansi 5\% dengan derajat kebebasan $(\mathrm{dk})=\mathrm{n}-1=22$ $-1=21$, hasil dieroleh untuk $t_{\text {tabel }}$ sebesar 2,080. Ini berarti thitung $>t_{\text {tabel. }}$ dan hasil dalam menentukan efektivitas dari perlakuan (treatment) yaitu sebesar 4,17 , termasuk kriteria efektivitas tinggi karena berada pada rentangan $0,8<$ ES. Berarti $\mathrm{H} 0$ ditolak dan $\mathrm{H} 1$ diterima sehingga dapat disimpulkan bahwa model explicit instruction menggunakan media video efektif digunakan untuk meningkatkan hasil belajar siswa dalam pembuatan pola busana wanita di SMK Negeri 1 Seririt.

Penerapan model explicit instruction menggunakan video pada mata pelajaran pembuatan pola busana wanita di kelas $X$ Tata Busana berlangsung lima kali pertemuan secara virtual dan satu kali pertemuan tatap muka dengan jumlah siswa yang dibatasi, kegiatan belajar mengajar seharusnya dilakukan secara langsung di dalam kelas secara tatap muka, namun dikarenakan situasi pandemi Covid-19 yang terjadi saat ini menyebabkaan proses belajar mengajar beralih menggunakan metode daring sesuai dengan Surat Edaran Nomor 4 Tahun 2020 Tentang Pelaksanaan Kebijakan Pendidikan Dalam Masa Darurat Penyebaran Corona Virus Disease (Covid19). Siswa diberikan perlakuan (treatment) terlebih dahulu seperti memberikan materi dan video pembelajaran secara virtual setelah itu siswa diberikan posttest berupa test objektif untuk menilai ranah kognitif, lembar observasi untuk menilai ranah afektif dan tes kinerja untuk menilai ranah psikomotor melalui media sosial (whatsapp).

Setiap siswa diminta untuk mendownload aplikasi google meet di handphone atau laptop yang terhubung dengan jaringan internet untuk melakukan pembelajaran, menyampaikan materi dan tujuan pembelajaran dengan penerapan model pembelajaran langsung secara virtual. Materi yang akan dipelajari sesuai dengan silabus dan RPP pembuatan pola busana wanita kelas X Tata Busana, kemudian siswa mempelajari materi tersebut dan video yang diberikan, setelah siswa mempelajari materi tersebut, siswa diberikan tugas membuat pola dasar busana wanita sesuai dengan materi yang telah dipelajari, pemberian tugas diberikan melalui sosial media. Sebelum mengakhiri pelajaran, guru memberikan kesempatan kepada siswa untuk berdiskusi atau tanya jawab untuk menyatukan pemahaman dan dapat menarik kesimpulan tentang pembelajaran yang telah dilakukan.

Model pembelajaran explicit instruction merupakan suatu pendekatan mengajar yang dapat membantu siswa dalam mempelajari keterampilan dasar dan memperoleh informasi yang diajarkan selangkah demi selangkah. Pendapat ini didukung oleh (Suyatno, 2009:127) menyatakan bahwa model pembelajaran explicit instruction adalah suatu pendekatan pembelajaran yang dirancang untuk mengembangkan kegiatan belajar mengajar siswa tentang pengetahuan deklaratif dan pengetahuan prosedural yang diajarkan selangkah demi selangkah. Penerapan model explicit instruction dinilai sangat tepat untuk diterapkan pada materi pembuatan pola dasar busana, karena mata pelajaran pembuatan pola merupakan mata pelajaran praktik yang tidak hanya mengajarkan sebatas pengetahuan namun juga mengajarkan keterampilan, agar siswa dapat memahami materi pembuatan pola dasar terstruktur dengan baik yang dapat diajarkan secara bertahap, selangkah demi selangkah. Pedapat ini didukung oleh Nikmatul Iza (2014) bahwa dalam pelaksanaan pembelajaran praktik disarankan guru menerapkan model pembelajaran langsung karena arena model pembelajaran langsung merupakan model pembelajaran yang dirancang untuk menunjang terlaksananya proses belajar setiap siswa yang erat berkaitan dengan pengetahuan cara prosedural dan pengetahuan deklaratif yang terprogram dengan baik dan dapat dipraktikkan dengan pola kegiatan secara bertahap,selangkah demi selangkah, sehingga pembelajaran langsung dirasa sangat tepat untuk diterapkan pada mata pelajaran praktik. Dalam proses pembelajaran saat ini dengan menggunakan metode daring, maka dalam proses pembelajaran didampingi materi 
secara terpisah yang dapat dibaca oleh siswa agar proses belajar mengajar dengan menggunakan model explicit instruction dapat terlaksana sebagaimana mestinya. Sejalan dengan pernyataan Risa Dwi Lestari (2012) mengenai model explicit instruction bahwa siswa dapat dengan mudah memahami dan menguasai materi yang disampaikan dan pembelajaran menjadi lebih terstruktur. Dalam penerapan model pembelajaran explicit instruction dibantu juga dengan menggunakan media pembelajaran, media yang digunakan yaitu berupa video pembelajaran yang dapat menampilkan gambar/objek gerak serta pengajaran secara tutorial langsung kepada siswa sehingga siswa dapat lebih fokus dan menarik minat belajar siswa, siswa bisa lebih memahami dan mengetahui dengan jelas cara pembuatan pola dasar busana secara tahap demi tahap, siswa dapat mengulang-ulang materi yang belum dimengerti secara mandiri, Hal tersebut didukung oleh Nila Oktapiani (2014) dimana hasi penelitian menunjukan bahwa hasil belajar siswa yang diakumulasikan dari hasil belajar kognitif dan hasil kinerja berdasarkan standar nilai yang sudah ditentukan yakni siswa dinyatakan tuntas dengan Kriteria Ketuntasan Minimum (KKM) secara individu $\geq 75$ dan jika minimal $85 \%$ dari seluruh siswa dikelas mencapai skor $\geq 75$ maka ketuntasan belajar secara klasikal pada pembelajaran yang ditunjang dengan media video telah berhasil dicapai. Dari pengolahan data diketahui tingkat ketuntasan pada hasil belajar siswa adalah 92,60\% siswa dinyatakan tuntas belajar.

Penggunaan media pembelajaran dapat meningkatkan hasil belajar siswa karena pembelajaran yang disampaikan oleh guru dapat membekas pada siswa dan media juga digunakan sebagai alat perantara dalam pembelajaran yang memudahkan kegiatan melajar mengajar agar tercapainya tujuan pembelajaran.. Pendapat ini didukung oleh (Aswan dan Syaiful, 2006:139) menyatakan bahwa selain memudahkan pelajaran, media juga dapat memberikan pengalaman yang berbanding lurus dari tidak paham menjadi paham. Media pembelajaran berupa video dalam pembelajaran saat ini yang menggunakan metode daring dapat digunakan sebagai alternatif dalam proses belajar mengajar, menghilangkan kebosanan siswa pada saat belajar, dan dapat meningkatkan hasil belajar siswa, karena media video menghasilkan gambar dan suara. Hal tersebut didukung oleh Siska Handayani (2018) dimana hasil penelitian menunjukan bahwa terdapat pengaruh secara signifikan dalam penerapan media video mampu meningkatkan hasil belajar siswa.

Terkait dengan hasil yang diperoleh penulis, terdapat hasil penelitian pendukung yang dilakukan oleh I Made Madalika (2016) dari Universitas Pendidikan Ganesha bahwa penerapan model direct instruction (pembelajaran langsung) berbantuan media audio visual berhasil diterapkan dan hasil penelitian menunjukan terjadi peningkatan persentase hasil belajar dengan penerapan model direct instruction (pembelajaran langsung) berbantuan media audio visual.

Penelitian lain yang sejalan adalah penelitian oleh Dewi Rosita,dkk (2016) dari Universitas Mulawarman bahwa hasil analisis data dan pembahasan terdapat pengaruh hasil belajar dengan menggunakan model explicit instruction dengan menggunakan media video pembelajaran terhadap hasil belajar. Dimana hasil belajar siswa yang menerapkan model pembalajaran explicit instruction dengan menggunakan video lebih baik dari hasil belajar siswa yang diajarkan dengan menggunakan model konvensional.

Penelitian lain yang juga sejalan adalah penelitian dari Alfian Basuseh Arif (2018) dari Universitas Negeri Surabaya bahwa hasil analisis data dan pembahasan rata-rata kelas experiment dan kelas kontrol menunjukan terdapatnya perbedaan hasil belajar antara siswa yang mendapatkan perlakuan dengan siswa yang tidak mendapatkan perlakuan. jadi Penerapan model pembelajaran langsung dengan berbantuan media video dapat meningkatkan hasil belajar siswa.

Berdasarkan hal tersebut di atas maka dapat dinyatakan bahwa model explicit instruction menggunakan media video efektif digunakan untuk 
meningkatkan hasil belajar pembuatan pola busana wanita di SMK Negeri 1 Seririt.

\section{SIMPULAN}

Berdasarkan hasil penelitian dan pembahasan yang telah dilakukan maka dapat disimpulan bahwa model explicit instruction menggunakan media video efektif digunakan untuk meningkatkan hasil belajar pembuatan pola busana wanita di SMK Negeri 1 Seririt Hal ini ditunjukan oleh hasil Berdasarkan hasil perhitungan uji-t adalah 19,86 dan memiliki tingkat efektivitas sebesar 4,17, termasuk kriteria efektivitas tinggi.

\section{SARAN}

Adapun beberapa saran yang dapat peneliti sampaikan berdasarkan penelitian yang telah dilakukan adalah sebagai berikut:

1. Bagi Siswa : Melalui penelitian ini, siswa diharapkan mampu mengikuti pembelajaran dengan baik yang telah dirancang oleh guru guna mencapai tujuan pembelajaran dan siswa juga dapat mengukur sendiri kemampuannya saat belajar dengan cara mengulang-ulang video pembelajaran yang telah diberikan.

2. Bagi Guru : Melalui penelitian ini, guru diharapkan dapat lebih terampil dalam merancang metode dan media pembelajaran yang sesuai dengan materi pembelajaran agar berjalan secara efektif. Dengan demikian, dapat memaksimalkan ketercapaian pembelajaran dan dapat menarik minat peserta didik untuk mengikuti pembelajaran pembuatan pola busana wanita.

3. Bagi Sekoalah : Dengan diadakannya penelitian ini, diharapkan model explicit instruction menggunakan media video pembelajaran ini dapat dimanfaatkan sebaik mungkin sebagai salah satu model pembelajaran dan media pembelajaran yang dapat membantu proses pembelajaran siswa, serta sekolah diharapkan memberi perhatian pada fasilitas belajar siswa agar siswa dapat belajar dengan nyaman.

4. Bagi Peneliti Lain : Berdasarkan penelitian ini, diharapkan bagi peneliti lain dapat mengembangkan model pembelajaran dan media pembelajaran pada mata pelajaran yang lain guna membantu dan memudahkan siswa dalam proses pembelajaran. Penelitian ini diharapkan dapat digunakan refrensi untuk melaksanakan penelitian selanjutnya.

\section{DAFTAR RUJUKAN}

Afandi, dkk. 2013. Model dan Metode Pembelajaran di Sekolah. Semarang: Unissula Press

Arif, Alfian Basuseh. 2018. Penerapan Model Pembelajaran Langsung Dengan Media Video Pada Mata Pelajaran Teknik Ukur Tanah di SMK Negeri 3 Surabaya. Surabaya: Universitas Negeri Surabaya.

Dantes, N. 2017. DESAIN EKSPERIMEN DAN ANALISIS DATA. Despok: Rajawali Pers.

Djamarah, Syaiful Bahri dan Aswan Zain. 2006. Strategi Belajar Mengajar. Cetakan ke-3. Jakarta: Rineka Cipta.

Handayani, Siska. 2018. Penerapan Media Video Pembelajaran Pada Kompetensi Dasar Membuat Pola DasarRok Secara Kontruksi Di Kelas $X$ Tata Busana 3 SMK Negeri 6 Surabaya. E-Journal. Volume 07 Nomor 02 Tahun 2018. Surabaya: Universitas Negeri Surabaya.

Iza,Nikmatul. 2014. Penerapan Model Pembelajaran Langsung Dengan Video Untuk Meningkatkan Hasil Belajar Siswa Pada Materi Membuat Pola Celana Di SMK Negeri 1 Baureno-Bojonegoro. E-Journal. Volume 03 Nomor 03 Tahun 2014. Surabaya: Universitas Negeri Surabaya. 
Lestari, Risa Dwi. 2012. Penerapan Model Pembelajaran Langsung Dengan Media Jobsheet Untuk Meningkatkan Kompetensi Pembuatan Saku Passepoile di SMK N 6 Purworejo. Yogyakarta: Universitas Negeri Yogyakarta.

Mandalika, I Made. 2016. Penerapan Model Direct Instruction (Pembelajaran Langsung) Berbantuan Media Audio Visual Dalam Pembelajaran Pekerjaan Dasar Elektromekanik Untuk Meningkatkan Hasil Belajar Siswa Kelas $X$ TITLI SMK Negeri 3 Singaraja. Singaraja: Universitas Pendidikan Ganesha.

Oktapiani,Nila. 2014. Pembelajaran langsung Ditunjang Media Video Pada Kompetensi Membuat Pola Dasar Badan Atas Teknik Draping Di Kelas X Busana Butik 2 SMKN 6 Surabaya. E-Journal. Volume 03 Nomor 01 Tahun 2014. Surabaya: Universitas Negeri Surabaya.

Rosita, Dewi,dkk. 2016. "Pengaruh Model Explicit Instruction Dengan Menggunakan Media Video Pembelajaran Terhadap Hasil Belajar Keterampilan Computer Dan
Pengelolaan Informasi (KKPI) (Studi Kasus : SMK Negeri 9 Samarinda). SEMNASAPTIKOM 28-29 Oktober 2016.

Sanjaya, Wina. 2011. Perencanaan dan Desai Sistem Pembelajaran. Jakarta: Kencana.

Sujadna,Nana. 2004. Penilaian Hasil Proses Belajar Mengajar. Bandung: PT Remaja Rosdakarya

Surat Edaran Nomor 4 tahun 2020 "Pelayanan Penyebaran Kebijakan Pendidikan Dalam Masa Darurat Penyebaran Corona Virus Disease (COVID-19)".

Suyatno. 2009. Menjelajah Pembelajaran Inovatif. Surabaya: Media Buana Pustaka.

Undang-Undang Republik Indonesia Nomor 20 Tahun 2003 "Sistem Pendidikan Nasional".

Undang-Undang Republik Indonesia Nomor 2 Tahun 1989 "Sistem Pendidikan Nasional".

Undang-Undang Nomor 17 Tahun 2010 "Pengelolaan dan Penyelenggaraan Pendidikan". 